\title{
KLONING \\ MANFAAT VERSUS MASALAH
}

\author{
Sunny Wangko ${ }^{1}$ \\ Erwin Kristanto ${ }^{2}$
}

\author{
${ }^{1}$ Bagian Anatomi-Histologi Fakultas Kedokteran Universitas Sam Ratulangi Manado \\ ${ }^{2}$ Bagian Kedokteran Forensik dan Medikolegal \\ Fakultas Kedokteran Universitas Sam Ratulangi Manado \\ Email: sunnywangko@yahoo.com
}

\begin{abstract}
In general, cloning is an asexual creation of a cell or organism which is genetically identical to its ancestor. Actually, cloning of unicellular and multicellular organisms has been going on in the natural world for thousands of years. Nowadays, in biotechnology, artificial cloning processed by using non-embryonic somatic cells is unbelievably well developed. In medical application, cloning is pointed to therapeutic, reproductive, and replacement usages. However, there are still many controversies, especially if this cloning is related to human beings, law, and ethics norms.
\end{abstract}

Keywords: cloning, cell, organism

\begin{abstract}
Abstrak: Kloning adalah kreasi secara aseksual dari suatu sel atau organisme yang merupakan salinan genetik dari organisme pendahulu. Secara alamiah kloning telah ditemukan sejak beribu-ribu tahun yang lalu pada organisme unisel sampai ke yang multisel. Dewasa ini kemajuan bioteknologi dalam melakukan kloning artifisial dengan menggunakan sel non embriogenik telah berkembang pesat. Pemanfaatan kloning dalam aplikasi medik ditujukan untuk pengobatan, reproduksi, dan replacement. Walaupun demikian, dalam hal pemanfaatannya masih banyak ketidak sesuaian pendapat, terlebih lagi bila masalah kloning terkait langsung dengan nilai-nilai kemanusiaan, hukum, dan etik.
\end{abstract}

Kata kunci: kloning, sel, organisme

Dewasa ini kloning telah menjadi "the hottest topic" dalam studi bioteknologi dan biomedik. Kloning yang dipelopori oleh Dreisch pada akhir tahun 1800 telah berkembang pesat dan menyumbangkan penemuan-penemuan baru yang sangat menjanjikan. Secara umum kloning merupakan sejumlah proses yang dapat digunakan untuk menghasilkan salinan suatu kesatuan biologik yang secara genetik identik tanpa melalui reproduksi seksual. Bahan salinan ini disebut klon (clone) dan mempunyai genetik yang sama dengan asalnya.

Pada hakekatnya secara alamiah kloning organisme unisel sampai ke yang multisel telah berlangsung selama ribuan tahun., ${ }^{1,3-5}$
Sebagai contoh, bakteri menghasilkan turunannya melalui proses reproduksi aseksual, sel kanker yang beranak pinak dalam tubuh manusia, tumbuhan dalam hutan sejenis, bahkan sampai organisme multisel yang lebih tinggi yaitu mamalia, termasuk manusia. Kembar identik pada manusia dan mamalia terjadi bila sel telur yang telah difertilisasi membelah dan menghasilkan dua atau lebih embrio yang menyandang DNA yang hampir identik.,

Dengan kemajuan biotekonologi maka terdapat perkembangan pesat dalam kloning artifisial. Keberhasilan melakukan kloning pada mamalia dengan menggunakan sel non embrionik yang diawali oleh hot issue 
'Dolly the sheep' (1997) telah membuka wawasan penelitian biomolekular dan bioteknologi yang sangat luas. 'Dolly the sheep' telah menularluaskan penelitian biomolekuler dengan menggunakan spesies lain. ${ }^{1,3}$ Sebagai umpan balik muncul isu-isu yang berlandaskan kode etik dan hukum, terlebih lagi setelah tebersitnya celah untuk dilakukannya kloning manusia. ${ }^{1,3,7-9}$

Pemanfaatan kloning dapat sebagai terapeutik, reproduktif, dan replacement. Kloning gen yang menghasilkan salinan gen atau segmen DNA dan kloning sel punca ataupun sel dewasa dapat diaplikasikan dalam pengobatan; kloning reproduktif menghasilkan salinan hewan seutuhnya (termasuk manusia); dan sebagai replacement yaitu berfungsi untuk penggantian bagian tubuh individu (yang dilakukan kloning) yang mengalami kerusakan, atau gagal organ. Salah satu isu yang cukup menggemparkan adalah menghasilkan klon manusia sebagai replacement children dengan menggunakan sel somatik dari individu itu sendiri. ${ }^{46-8}$

Masih banyak kendala, salah tanggap, ataupun kontroversi dalam proses kloning ini, baik dalam hal teknologi, penelitian dan pengamatan, maupun tanggapan dari pihakpihak yang berkompeten, terlebih lagi bila kloning yang terkait langsung dengan nilainilai kemanusiaan, hukum, dan etik. ${ }^{4,6,9} \mathrm{Wa}$ laupun demikian bagi para peneliti biomolekuler, kloning masih tetap merupakan topik yang sangat menarik, marak dan penuh dengan tantangan, dan amat sangat patut diperjuangkan demi kemajuan masa depan. Diperlukan waktu yang cukup panjang untuk menentukan apakah impian para peneliti akan terwujud atau tetap status quo sebagai masalah serius dan mendasar secara etik, terlebih lagi mengenai keberadaan dan status moral embrio manusia dan penggunaannya dalam penelitian.

\section{PEMAHAMAN KLONING}

Di dalam ilmu biologi kloning adalah proses untuk menghasilkan populasi individu yang identik secara genetik, yang terjadi di dalam alam ketika organisme seperti bak- teri, insekta, atau tumbuhan bereproduksi secara aseksual. Secara lebih rinci Bioteknologi menjelaskan kloning sebagai proses untuk menghasilkan salinan fragmen DNA (kloning molekular), sel (kloning sel), atau organisme (kloning organisme). ${ }^{2}$

Terdapat beberapa definisi yang berkaitan dengan kloning

\section{Terminologi}

Clone berasal dari kata bahasa Junani $\kappa \lambda \Omega v$ yang berarti batang atau cabang; istilah ini mengacu ke proses dimana tanaman yang baru dihasilkan dari cabang atau ranting. Dalam ilmu perkebunan (horticulture), istilah clon dipakai sampai abad ke20, yang kemudian berkembang menjadi clone, yang masih digunakan sampai dewasa ini. ${ }^{2}$

\section{Oxford Dictionary}

Menurut Oxford Advanced Learner's Dictionary clone adalah satu kelompok tumbuhan atau organisme yang dihasilkan secara aseksual dari satu pendahulu (ancestor). ${ }^{10}$

\section{Encyclopedia Britannica}

Encyclopedia Britannica menyebutkan clone (whole organism cloning) sebagai organisme individual yang tumbuh dari satu sel tubuh tunggal orang tuanya yang secara genetik identik. ${ }^{1}$

\section{Biomolekul}

Kloning adalah kreasi suatu organisme yang merupakan salinan genetik dari organisme pendahulu. ${ }^{5}$ Clone adalah salinan genetik yang iden-tik dari potongan DNA, sel, atau orgisme keseluruhan. ${ }^{11}$

\section{SEJARAH}

Pada tahun 1800 Hans Dreisch memelopori melakukan kloning pada sea urchins dengan dasar pemikiran hewan laut ini mempunyai sel embrio yang besar dan dapat berkembang tanpa ketergantungan pada induknya. Dreich melakukan kloning de- 
ngan memisahkan sel embrio bersel dua. ${ }^{3}$ Selang 20 tahun kemudian yaitu tahun 1902 Hans Spemman berhasil melakukan pemisahan sel embrio bersel dua dari salamander, yang selanjutnya berkembang diluar tubuh induk. Perkembangan yang pesat terjadi pada 1951 oleh tim peneliti di Philadelphia yang melakukan kloning embrio katak. Inti sel embrio katak dikeluarkan untuk menggantikan inti sel telur yang belum dibuahi. Percobaan ini merupakan awal metode nuclear transplant. ${ }^{1,3}$

Penerobosan yang bermakna terjadi pada tahun 1986 dengan dilakukannya koning mamalia oleh dua tim peneliti di Inggris (kloning biri-biri) dan di Amerika (kloning sapi). Walaupun demikian, tidak satupun tim yang berpendapat bahwa kloning mamalia dapat dilakukan dengan menggunakan sel somatik dewasa yang telah berdiferensiasi. Tahun 1996 tim peneliti Wilmut et al dari Roslin Institute di Scotlandia berhasil melakukan kloning biri-biri dengan menggunakan sel nonembrionik yaitu sel kelenjar mamma biri-biri dewasa, yang dikenal dengan "Dolly the sheep". Dengan berhasilnya proses kloning tersebut, maka penelitipeneliti lainnya berlomba-lomba melakukan kloning dengan menggunakan berbagai spesies hewan. $1,2,3,5$

\section{METODE MELAKUKAN KLONING}

Secara umum dikenal beberapa cara untuk melakukan kloning: ${ }^{1,5,8}$

\section{Artificial embryo twinning}

Cara ini relatif lowtech, yang mencontohi proses alamiah terjadinya kembar identik. Pada embrio yang masih dini dilakukan separasi secara manual sehingga menghasilkan sel-sel individu, yang selanjutnya akan membelah dan berkembang. Embrio ini diimplantasikan pada inang subtitusi sampai cukup bulan dan kemudian dilahirkan. Oleh karena embrio-embrio klon ini berasal dari zigot yang sama maka mereka secara genetik identik.

\section{Somatic cell nuclear transfer (SCNT)}

Cara ini agak berbeda dengan artificial embryo twinning tetapi memberi hasil yang relatif sama yaitu salinan genetik yang sama. Sel somatik yang dipakai adalah selsel di dalam tubuh selain sel sperma dan sel telur. Pada mamalia setiap sel somatik mempunyai dua set kromosom yang lengkap. Inti sel somatik ditransfer ke sel telur yang telah dilakukan enukleasi. Sel telur dengan inti baru ini akan berlaku sebagai zigot, yang kemudian diimplantasikan ke inang subtitusi. SCNT bertujuan utama untuk menghasilkan embrio yang akan digunakan pada riset, terutama riset sel punca. Selsel ini kemudian dipanen untuk digunakan pada riset bioteknologi dengan harapan dapat diaplikasikan bagi berbagai aspek yang menunjang kesejahteraan manusia, termasuk aspek kesehatan dan pengobatan.

\section{JENIS KLONING}

Dewasa ini terdapat beberapa jenis kloning yang telah diteliti: ${ }^{2,11}$

\section{Kloning molekul (Molecular cloning)}

Di dalam alam DNA tersusun sangat panjang dimana satu molekul tunggal menyandang banyak gen. Untuk organisme multisel gen menempati hanya sebagian kecil dari DNA kromosom; sisanya merupakan sekuens nukleotid yang berulang dan noncoding. Sebagai contoh, gen manusia menyusun 1/100.000 molekul DNA dimana ia terdapat. Kloning DNA bertujuan menghasilkan sejumlah besar DNA yang identik, termasuk gen, promotor, sekuens noncoding, dan fragmen DNA, untuk penelitian lanjut atau menggunakan DNA pada organisme yang intak untuk menghasilkan protein yang bermanfaat baik bagi penelitian maupun aplikasi bagi kesehatan manusia.

Kloning dilakukan dengan menggunakan bakteri dan plasmid. Plasmid merupakan molekul DNA sirkular berukuran kecil, tetapi mempunyai ukuran sama atau bahkan lebih besar dari ukuran bahan genetik utamanya (kromosom bakteri), dan bereplikasi di dalam sel bakteri. ${ }^{12,13}$ Dalam hal melakukan kloning gen atau potongan DNA, plasmid asal (cloning vector) diisolasi dari sel bakteri. Gen sel tertentu disisipkan ke 
dalam plasmid, sehingga terbentuk plasmid dengan DNA rekombinan. Plasmid yang baru dimasukkan ke dalam sel bakteri, dan terbentuk bakteri rekombinan yang akan membentuk sel klon. Gen yang disisipkan akan terikut pada bakteri yang bermitosis. Klon bakteri ini akan menghasilkan protein yang sesuai dengan gen yang disisipkan. Produk protein yang dihasilkan dapat digunakan untuk penelitian lanjut atau diaplikasikan bagi kesehatan manusia ataupun bidang lainnya. Sebagai contoh perusahaan farmasi menghasilkan berbagai jenis hormon dengan menggunakan bakteri yang menyandang gen manusia. Gen yang resisten terhadap hama dari satu spesies dapat diklon dan disisipkan ke spesies yang lain. ${ }^{13}$

Secara umum kloning fragmen DNA mencakup lima langkah strategi kloning: ${ }^{2,11}$

\section{Isolasi}

Isolasi dan pemurnian DNA sel sampel

\section{Fragmentasi}

Fragmentasi dengan menggunakan enzim restriksi yang memisahkan untaian DNA

\section{Ligasi}

Ligasi untuk melekatkan potonganpotongan DNA dalam sekuens yang diinginkan. Fragmen DNA dicampurkan dengan plasmid yang telah dipotong dengan enzim restriksi yang sama. DNA ligase ditambahkan untuk mengikatkan fragmen DNA ke plasmid.

\section{Transfeksi}

Transfeksi untuk menyisipkan potongan baru DNA ke dalam sel.

\section{Seleksi}

Skrining/seleksi: seleksi sel-sel yang berhasil ditransfeksi dengan DNA baru.

\section{Kloning sel ${ }^{2,11}$}

Kloning sel bertujuan menghasilkan suatu populasi sel dari satu sel tunggal. Pada organisme unisel seperti bakteri dan jamur, proses ini relatif mudah dan hanya memerlukan inokulasi pada media yang sesuai. Pada kultur sel dari organisme multisel, baik sel dewasa maupun sel punca, kloning sel merupakan hal yang cukup rumit karena sel-sel ini tidak dapat tumbuh pada media standar. Tehnik yang diperkenalkan adalah dengan menggunakan cincin kloning. Suspensi sel tunggal yang telah dipapar dengan agen mutagenik atau obat tertentu ditempatkan pada pengenceran tinggi untuk menghasilkan koloni-koloni yang terisolasi. Setiap koloni tumbuh dari satu sel tunggal. Sel-sel klon dikumpulkan dari dalam cincin dan dipindahkan untuk pertumbuhan lanjut.

\section{Kloning organisme $e^{2,11}$}

Disebut juga kloning reproduksi yang bertujuan untuk menghasilkan organisme multisel yang identik secara genetik. Proses kloning ini merupakan reproduksi aseksual dimana tidak terjadi fertilisasi. Disini dilakukan transfer inti dari sel dewasa donor ke dalam sel telur tanpa inti. Bila sel telur telah membelah normal maka akan dipindahkan ke dalam uterus inang substitusi. Klon yang dihasilkan tidak sepenuhnya identik oleh karena sel somatik dapat mengandung mutasi DNA inti. Selain itu mitokondria di dalam sitoplasma juga mengandung DNA, dan selama SCNT, DNA ini sepenuhnya berasal dari sel telur donor, jadi genom mitokondria tidak serupa dengan sel telur donor. Hal ini sangat perlu diperhatikan pada cross species nuclear transfer oleh karena bila terjadi incompatbilitas mitokondria maka akan mengarah ke kematian sel. Selain itu dalam proses kloning peran kromosom seks (inaktivasi) belum dapat dipenuhi. ${ }^{4}$

Secara umum proses kloning pada mamalia dan manusia serupa, tetapi aplikasi pengunaan klon pada manusia lebih kompleks. Kloning dapat berfungsi sebagai terapeutik, reproduktif, dan replacement. ${ }^{2,9}$ Kloning terapeutik merupakan kloning sel punca ataupun sel dewasa untuk diaplikasikan pada pengobatan dan penelitian. Kloning reproduktif secara teoritik untuk membentuk klon manusia. Kloning replacement merupakan gabungan keduanya, dan berfungsi untuk penggantian bagian tubuh individu yang dilakukan kloning yang 
mengalami kerusakan, atau gagal organ, dan diikuti oleh transplantasi otak sebagian atau seluruhnya. Salah satu keuntungan bila menggunakan klon organ dari diri sendiri yaitu tidak terjadi reaksi penolakan jaringan, dan dengan sendirinya tidak memerlukan pemberian obat imunosupresif. Koning replacement masih mendapat banyak tantangan karena belum terdapat persesuaian pendapat mengenai hasil klon, antara lain apakah sudah layak pakai atau belum., 2,4,

Walaupun kloning telah berhasil dilakukan pada berbagai spesies, pemahaman mengenai proses cloning subselular dan molecular masih sangat terbatas. Aborsi, lahir mati dan perkembangan yang abnormal pada hewan klon masih sangat tinggi, yang menunjukkan bahwa tingkat efisiensi dan keamanan SCNT masih belum meyakinkan. Masalah lain yang cukup serius adalah pemendekan telomer. Telomer merupakan sekuens DNA berulang pada ujung kromosom. Dengan bertambahnya usia hewan telomer akan memendek. Bila telomer sel sudah sangat memendek, maka sel tersebut akan mati. Bila klon diambil dari sel yang tua, maka telomerya pun akan memendek yang mengakibatkan kecenderungan menderita penyakit dan mengalami kematian pada usia yang relatif muda. ${ }^{8,14,15}$

\section{PRO DAN KONTRA TERHADAP KLONING}

Walaupun kloning merupakan lahan penelitian yang melibatkan berbagai disiplin ilmu yang bernaung di bawah biomolekular dan bioteknologi, masih terdapat banyak tantangan, ketidak sesuaian paham, ataupun oposisi dari berbagai pihak, terlebih lagi bila berkaitan dengan etik, kepercayaan/agama, dan hukum. Berbagai masalah dalam bidang pertanian seperti pemanfaatan tanaman transgenik untuk dikonsumsi oleh manusia; dalam bidang peternakan yang menghasilkan klon hewan yang dibesarkan tanpa induk, apakah kelak dapat berperan secara alamiah; kloning spesies yang telah punah untuk mempertahankan atau memulihkan ekosistem apakah memang dibutuhkan, dan dapat menggantikan peran spesies tersebut pada saat sekarang; kloning hewan tertentu seperti babi untuk aplikasi xenotransplantation; kloning sel atau organ manusia untuk kepentingan terapeutik, dan lain sebagainya masih memerlukan banyak pemahaman yang meyakinkan dan persesuaian pendapat, baik secara etik, moral, dan hukum. ${ }^{1,2,8,9}$

\section{PENDEKATAN ETIK DAN HUKUM KLONING PADA MANUSIA}

Setelah diungkapnya kasus Dolly the sheep di Edinburgh 1997, UNESCO mempublikasikan Declaration on the human genome and human rights yang ditandatangani oleh 186 negara, yang melarang reproduksi manusia melalui proses kloning. ${ }^{16}$

Secara etik, pendekatan pertama adalah bahwa secara fundamental proses kloning adalah teknologi yang masih dalam pengembangan dan belum cukup aman untuk diaplikasikan pada subjek manusia. Pengembangan teknologi kloning masih memerlukan banyak perbaikan untuk mengatasi penuaan dini seperti yang terjadi pada Dolly the sheep, dan dihasilkannya sejumlah besar embrio dengan malformasi.

Bila di kemudian hari kloning menjadi teknologi yang aman, masih perlu pula dikaji apakah kloning dapat membawa malapetaka psikologis bagi para "clone". Kesadaran bahwa mereka kehilangan kesempatan untuk menjadi unik, beban harapan orang tua clone yang mungkin terlalu besar, penerimaan lingkungan terhadap clone, dan melihat dengan langsung seperti apa dirinya pada berbagai usia melalui orang tuanya masih perlu pertimbangan masak. Akan selalu dibayangi bahaya bahwa dengan teknologi ini, masyarakat akan melihat anak hasil kloning (clone) sebagai komoditas barang dan bukan sebagai satu sosok pribadi manusia seutuhnya. Komoditas tersebut dapat diperdagangkan untuk kepentingan transplantasi organ, tenaga kerja, kemiripan bentuk fisik dengan seorang figur, maupun ekploitasi lainnya.

Dari pandangan sisi yang berbeda masih akan timbul pula permasalahan seperti 
individu bagaimana yang berhak memperoleh clone? Apakah kloning dikehendaki dengan alasan moral yang dapat diterima? Sebagai contoh, membesarkan seorang clone dengan alasan untuk menyediakan cadangan organ bagi seseorang tentu saja tidak dapat diterima. Pada UU no.36 tahun 2009 pasal 65 disebutkan bahwa "Pengambilan organ dan/atau jaringan tubuh dari seorang donor harus memperhatikan kesehatan yang bersangkutan dan mendapat persetujuannya." Persetujuan pendonor dalam keadaan yang tidak cakap hukum karena satu dan lain hal juga membuat kloning bukan teknologi yang tepat digunakan untuk alasan di atas. ${ }^{17}$

Di pihak lain teknologi sel punca mungkin merupakan jawaban atas problematika tertentu di bidang pelayanan kedokteran, dimana hal ini telah di atur dalam UU no.36 tahun 2009 pasal $70 .^{17}$

\section{KESIMPULAN}

Secara umum kloning merupakan sejumlah proses yang dapat digunakan untuk menghasilkan salinan suatu kesatuan biologik baik dari potongan DNA, sel, atau organisme keseluruhan yang secara genetik identik tanpa melalui reproduksi seksual. Terdapat beberapa cara untuk melakukan cloning yaitu artificial embryo twinning dan somatic cell nuclear transfer (SCNT). Pada manusia kloning dapat berfungsi sebagai terapeutik, reproduktif, dan replacement. Sangat diharapkan penelitian kloning akan lebih diminati dan dapat berkembang pesat untuk menunjang tercapainya 'quality of life' yang layak.

\section{DAFTAR PUSTAKA}

1. Cloning-A Webliography [homepage on the Internet]. Nodate [cited 2010 Jan 20]. Available from: http://staff.lib.msu,cdu/skendall/cloning/

2. Cloning [homepage on the internet]. Nodate [cited 2010 Jan 20]. Available from: http://en.wikipedia.org/wiki/Cloning

3. History of cloning [[homepage on the Internet]. Nodate [cited 2010 Jan 20]. Available

from:
http://library.thinkquest.org/2080/Frame less/Manipulating/experimentation/cloni ng/longdoc.htm

4. National Human Genome Research Institute. Cloning [homepage on the Internet]. Nodate [cited 2010 Jan 20]. Available from: http://ww.genome.gov/25020028

5. What is cloning? [homepage on the Internet]. Nodate [cited 2010 Jan 20]. Available from: http://learn.genetics.utah.edu/content/teh /cloning/whatiscloning/

6. Beddington R. Cloning. NIMR: Mill Hill Essays, 1997.

7. Society, Religion and Technology Project Church of Scotland: Looking at the ethics of technology for a New Millenium [homepage on the Internet]. c2010 [cited 2010 Jan 20]. Available from:

http://www.srtp.org.uk/cloning.shtml

8. Stanford Encyclopedia of Philosophy. Cloning [homepage on the Internet]. Nodate [cited 2010 Jan 20]. Available from:

http://plato.stanford.edu/entries/cloning/

9. Human cloning [homepage on the Internet]. Nodate [cited 2010 Jan 20]. Available from:

http://en.wikipedia.org/wiki/Human_clo ning

10. Hornby AS. Oxford Advanced Learner's Dictionary. Oxford: Oxford University Press, 1990; p. 212.

11. Riyanda NG, Vina EA, Arini N, Suluh N. Recombinant DNA and Cloning [homepage on the Internet]. Nodate [cited 2010 Jan 20]. Available from: http://faperta.ugm.ac.id/newbie/downloa d/pak_tar/genetikamolekuler/presentasi/Recombinant $\% 20$ DNA\%20and\%20Cloning.ppt

12. Yuwono T. Organisasi biologis jasad hidup. Dalam: Biologi Molekular. Jakarta: Erlangga, 2008; p. 10.

13. Campbell NA, Reece JB, Mitchell LG. DNA technology. In: Biology $5^{\text {th }}$ ed. California: AddisonWesley Longman Inc, 1999; p. 364-70.

14. Hornsby PJ. Telomerase and the aging process [homepage on the Internet]. Nodate [cited 2010 Jan 20]. Available from:

http://www.ncbi.nlm.nih.gov/pmc/articl 
94 Jurnal Biomedik, Volume 2, Nomor 2, Juli 2010, hlm. 88-94

es/PMC19335871

15. Telomere [homepage on the Internet]. Nodate [cited 2010 Jan 20]. Available from:

http://en.wikipedia.org/wiki/Telomere

16. Idries AM, Tjiptomargono A. Peran ilmu kedokteran forensik untuk kepentingan penyidikan. Jakarta: Sagung Seto, 2008.

17. Kementerian Kesehatan. Undang-undang nomor 36 tahun 2009 tentang kesehatan. Jakarta: Sekretariat Negara, 2009. 